\title{
Decaspirones A-E, New Bioactive Spirodioxynaphthalenes from the Freshwater Aquatic Fungus Decaisnella thyridioides
}

\author{
Ping Jiao ${ }^{\dagger}$, Dale C. Swenson ${ }^{\dagger}$, James B. Gloer ${ }^{*} \dagger$, Jinx Campbell ${ }^{\ddagger}$, and Carol A. Shearer ${ }^{\ddagger}$ \\ Department of Chemistry, University of lowa, lowa City, IA, 52242 and Department of Plant Biology, \\ University of Illinois, Urbana, IL, 61801
}

\begin{abstract}
Decaspirones A-E (1-5), five new compounds related to the palmarumycins, were isolated from cultures of the freshwater aquatic fungal species Decaisnella thyridioides. The known compound palmarumycin $\mathrm{CP}_{1}(\mathbf{6})$ was also obtained. The structures of $\mathbf{1 - 5}$ were determined by analysis of NMR and MS data, and their relative configurations were assigned by analysis of ${ }^{1} \mathrm{H}$ NMR $J$-values and NOESY data. The structure of the lead compound 1 was confirmed by X-ray crystallographic analysis. Compounds 1-5 possess a trans ring fusion not previously reported in members of this structural class. The absolute configuration of $\mathbf{1}$ was assigned using the modified Mosher method. Compounds 1-5 showed potent antifungal and antibacterial activity.
\end{abstract}

In our ongoing search for new bioactive fungal metabolites, we continue to investigate rarely studied ecological groups such as freshwater aquatic fungi. Prior investigations of freshwater fungi in our group have afforded a variety of bioactive metabolites. ${ }^{1-4}$ In the course of this work, an extract showing potent antifungal activity was obtained from cultures of an isolate of Decaisnella thyridioides (Sacc. \& Speg.) M. E. Barr (Pyrenulaceae) that was collected from submerged, decorticated wood in the Lemonweir river in Wisconsin. To our knowledge, no prior chemical study of any member of the genus Decaisnella has been reported. Investigation of this species afforded five new compounds containing dioxynaphthalene substructures, which were named decaspirones A-E (1-5), along with one related known compound (palmarumycin $\left.\mathrm{CP}_{1} ; \mathbf{6}\right){ }^{5}$ Decaspirones A-E belong to a growing family of fungal metabolites referred to as spirodioxynaphthalenes that includes palmarumycins, cladospirones, and diepoxins. ${ }^{5-11}$ These compounds display a wide range of biological activities, including antibacterial and antifungal effects, phospholipase D inhibitory activity, and antitumor activity. All of the spirodioxynaphthalene compounds reported to date incorporate a modified cis-decalin moiety. However, the decaspirones possess a trans-decalin system, making them the first examples of this class to incorporate a trans ring fusion. Details of the isolation, structure elucidation, and stereochemical assignments of decaspirones A-E (1-5) are presented here.

\section{Results and Discussion}

Solid-state fermentation cultures of $D$. thyridioides (A-00267-2A) were extracted with ethyl acetate and the resulting crude extract showed significant antifungal activity in disk assays against a Nectria species, Candida albicans, and Aspergillus flavus. Fractionation of this extract led to the isolation of decaspirones A-E (1-5) and the known spironaphthalene

\footnotetext{
* To whom correspondence should be addressed. Tel: 319-335-1361. Fax: 319-335-1270. E-mail: james-gloer@uiowa.edu.

$\dagger$ University of Iowa.

\$University of Illinois.
} 
compound palmarumycin $\mathrm{CP}_{1}(\mathbf{6})$. The structure of palmarumycin $\mathrm{CP}_{1}$ was established by comparison of NMR and MS data with literature values. ${ }^{5}$

Decaspirones A-E (1-5) were recognized as members of the spironaphthalene class by analysis of NMR data. The general characteristics of this class include the 1,8-dioxynaphthalene moiety linked with the second half of the molecule via a spiroketal carbon resonating at approximately $\delta_{\mathrm{C}} 100$. The NMR spectroscopic data for the dioxynaphthalene moiety and the bridging carbon atom of all five compounds were virtually identical, so the structure elucidation of these metabolites focused mainly on establishing the identities of the remaining portions of the molecules.

The molecular formula of decaspirone $\mathrm{A}(\mathbf{1})$ was determined as $\mathrm{C}_{20} \mathrm{H}_{16} \mathrm{O}_{5}$ (13 degrees of unsaturation) by analysis of MS, as well as ${ }^{1} \mathrm{H}$ NMR, and ${ }^{13} \mathrm{C}$ NMR data (see Tables 1 and 2). Aside from a set of NMR signals characteristic of the dioxynaphthalene moiety, the ${ }^{1} \mathrm{H}$ and ${ }^{13} \mathrm{C}$ NMR spectra showed signals for a ketal carbon, two 1,2-disubstituted olefin units, a ketone moiety, four contiguous $\mathrm{sp}^{3}$ methine units (two of which were oxygenated), and two hydroxy groups.

The connectivities among these units were determined by analysis of ${ }^{1} \mathrm{H}-{ }^{1} \mathrm{HCOSY}$ and $\mathrm{HMBC}$ data. COSY data revealed that one of the olefins was isolated, while the other was linked to the methine units to form a dioxycyclohexene spin-system that corresponded to the $\mathrm{C} 4 \mathrm{a}-\mathrm{C} 8 \mathrm{a}$ substructure in 1. HMBC correlations of $\mathrm{H}-2, \mathrm{H}-3$, and $\mathrm{H}-4$ a to ketone carbonyl $\mathrm{C}-4$, and of $\mathrm{H}-2$ and $\mathrm{H}-3$ to $\mathrm{C}-4 \mathrm{a}$, linked $\mathrm{C}-4$ to the $\mathrm{C}-2 / \mathrm{C}-3$ double bond and to $\mathrm{C}-4 \mathrm{a}$ of the cyclohexene ring. Correlations of $\mathrm{H}-3, \mathrm{H}-4 \mathrm{a}, \mathrm{H}-8 \mathrm{a}$, and $\mathrm{H}-8$ to ketal carbon $\mathrm{C}-1\left(\delta_{\mathrm{C}} 97.9\right)$ enabled the connection of the C-2/C-3 double bond and C-8a of the cyclohexene ring to C-1. The dioxynaphthalene unit must be linked to $\mathrm{C}-1$ via the two oxygen atoms from the ketal moiety, thereby completing the gross structure of $\mathbf{1}$ as shown.

A $13-\mathrm{Hz}$ coupling constant between the two bridgehead protons $\mathrm{H}-4 \mathrm{a}$ and $\mathrm{H}-8 \mathrm{a}$ indicated the presence of a trans ring fusion. However, the orientation of the two hydroxy groups at C-5 and $\mathrm{C}-8$ could not be established with confidence on the basis of $J_{\mathrm{H}-\mathrm{H}}$ values. NOESY data were consistent with proposal of the relative stereochemistry shown in $\mathbf{1}$, but any ambiguity was resolved upon X-ray crystallographic diffraction analysis of a crystal of $\mathbf{1}$ obtained from acetonitrile solution. The X-ray data confirmed the presence of the trans-decalin ring system (Figure 1) and revealed that the C-5 and C-8 hydroxy groups have a syn-relative orientation.

The molecular formula of decaspirone $\mathrm{B}(2)$ was determined to be $\mathrm{C}_{22} \mathrm{H}_{20} \mathrm{O}_{6}$ (13 degrees of unsaturation) on the basis of EIMS and NMR data. The presence of signals for one additional oxygenated methine group and an acetate unit in the ${ }^{1} \mathrm{H}$ NMR spectrum relative to that of $\mathbf{1}$ suggested reduction of the ketone carbonyl C-4 and acetylation of one of the hydroxy groups. Changes in the ${ }^{13} \mathrm{C}$ NMR spectrum were also consistent with these proposed differences. ${ }^{1} \mathrm{H}-{ }^{1} \mathrm{H}$ COSY correlations confirmed the presence of the new extended spinsystem, and were used to locate the acetate group at C-5, since the H-5 signal ( $\delta 5.92)$ was shifted downfield by $1.4 \mathrm{ppm}$ relative to that of compound $1 .{ }^{1} \mathrm{H}$ and ${ }^{13} \mathrm{C}$ NMR chemical shift assignments were confirmed by analysis of HMQC data. The relative stereochemistry was assigned to match that of compound $\mathbf{1}$ based on close similarities among the coupling constants of the signals for $\mathrm{H}-4 \mathrm{a}, \mathrm{H}-8 \mathrm{a}, \mathrm{H}-4$, and $\mathrm{H}-8$ for both compounds. This conclusion was confirmed and the relative stereochemistry of the new stereocenter at C-4 was assigned by analysis of NOESY data (Figure 2). Correlations of H-4 to H-4a and to the methyl singlet of the acetate unit led to placement of the C-4 hydroxy group anti to the hydroxy groups at C-5 and C-8. The resulting pseudo-equatorial orientation of $\mathrm{H}-4$ is consistent with the smaller vicinal coupling $(J=4.4 \mathrm{~Hz})$ observed between $\mathrm{H}-4$ and H-4a, in comparison to the $J$-value observed between $\mathrm{H}-4 \mathrm{a}$ and $\mathrm{H}-5$. 
Decaspirone $\mathrm{C} \mathrm{(3)}$ was assigned the molecular formula $\mathrm{C}_{20} \mathrm{H}_{18} \mathrm{O}_{5}$ on the basis of NMR and HREIMS data. Two additional hydrogens of the molecular formula relative to that of $\mathbf{1}$ and analysis of the ${ }^{1} \mathrm{H}$ NMR spectrum suggested that the C-6/C-7 double bond in $\mathbf{1}$ was reduced in 3. This was consistent with the ${ }^{13} \mathrm{C}$ NMR data, which included two new methylene carbon signals at $\delta_{\mathrm{C}} 26.9$ and 30.2 in place of the C-6 and C-7 olefin signals in the spectrum of $\mathbf{1}$. Proton and carbon shift assignments were made by analysis of HMQC and HMBC experiments. The relative stereochemistry was determined to be the same as that of $\mathbf{1}$ by analysis of NOESY data (Figure 2) and ${ }^{1} \mathrm{H}$ NMR coupling constants.

Decaspirones D (4) and E (5) were both readily identified as different monoacetylated products of compound $\mathbf{1}$. Both compounds showed a molecular ion peak at $\mathrm{m} / \mathrm{z} 378$, suggesting a molecular formula of $\mathrm{C}_{22} \mathrm{H}_{18} \mathrm{O}_{6}$, and the structures were assigned by analysis of ${ }^{1} \mathrm{H},{ }^{13} \mathrm{C}$, and COSY NMR data. In each case, the replacement of one hydroxy group signal with an acetate methyl singlet in the ${ }^{1} \mathrm{H}$ NMR spectrum indicated acetylation of one of the hydroxy groups. As a result, the H-8 signal in compound $\mathbf{4}$ was shifted downfield to $\delta 6.04$ ( $\delta 4.90$ in 1); while in $\mathbf{5}$, the H-5 signal moved downfield significantly compared with that of $\mathbf{1}(\delta 5.80$ vs $\delta$ 4.52). ${ }^{1} \mathrm{H}$ and ${ }^{13} \mathrm{C}$ NMR assignments were established by analysis of $\mathrm{HMQC}$ data. Based on similarities of the ${ }^{1} \mathrm{H}^{-1} \mathrm{H}$ coupling constant values with those observed for $\mathbf{1}$, compounds 4 and 5 were proposed to have the same relative configurations at C-4a, C-5, C-8, and C-8a as in $\mathbf{1}$.

The absolute stereochemistry of decaspirone A (1) was assigned by application of the modified Mosher method. ${ }^{12,13}$ One equivalent of $S$-MTPA Cl was added to a sample of $\mathbf{1}$ in an effort to obtain a mono- $R$-MTPA ester. Some selectivity for acylation of the C-8 hydroxy group was obtained, as indicated by NMR analysis, and the resulting product (1a) was isolated by reversed-phase HPLC. The process was then repeated with the $R$-MTPA Cl isomer to form the mono-S-MTPA ester (1) $)$. The differences in chemical shift values $\left(\Delta \delta=\delta_{S}-\delta_{R}\right)$ for the two diastereomeric esters $\mathbf{1 b}$ and $\mathbf{1 a}$ were calculated in order to assign the absolute stereochemistry at C-8 (Figure 3). The particularly dramatic effect for one of the protons ortho to the ketal linkage $\left(\mathrm{H}-2^{\prime}\right)$ is consistent with its placement on the same face of the modified decalin system as the MTPA ester unit. Calculations for all of the relevant signals except one (H-7) suggested the $R$-absolute configuration at $\mathrm{C}-8$. It is possible that the presence of the nearby 1,8 dioxynaphthalene moiety could cause this apparent anomalous result for the $\mathrm{H}-7$ signal, since some interaction between the MTPA phenyl group and the naphthalene moiety might occur to perturb the favored conformations from those adopted by typical MTPA esters. This concept was investigated using molecular modeling techniques (Spartan 02), but the results were inconclusive. Ultimately, the $5 S, 8 R, 4 \mathrm{a} S$, and $8 \mathrm{a} S$ absolute configuration was proposed for compound 1 on the basis of the vast majority of the $\Delta \delta$ results summarized in Figure 3 . The absolute configurations of compounds 2-5 were presumed to be analogous to that of $\mathbf{1}$.

Decaspirones A-E (1-5) are new members of the so-called spirodioxynaphthalene class with a trans-fused decalin ring system that is unprecedented among members of this class. ${ }^{14,15}$ These compounds seem likely to be somewhat more stable than their cis-ringfused counterparts, and most of them contain a proton $\alpha$ to a ketone moiety. However, there was no evidence of epimerization during the isolation process, as the major components were very abundant in the extract and were evident in the NMR spectrum prior to any separation efforts. In addition, the only prior literature examples with similar functionality contain cis ring fusions, and none of the corresponding cis analogs were detected in the D. thyridioides extract, even as minor analogs. Biogenetically, both the naphthalene and the decalin units are presumably derived from the polyketide pathway. ${ }^{16}$ Palmarumycin $\mathrm{CP}_{1}(\mathbf{6})$ can be considered as an aromatized dehydration product of decaspirone A.

In standard antibacterial disk assays, compounds 1-5 all showed significant activity against Bacillus subtilis (ATCC 6051) when tested at $50 \mu \mathrm{g} / \mathrm{disk}$, causing inhibition zones of 39, 19, 
34, 30, and $30 \mathrm{~mm}$, respectively. Compounds $\mathbf{1 , 3}$, and $\mathbf{4}$ were active against Staphylococcus aureus (ATCC 29213), causing zones of inhibition of 41, 28, and $30 \mathrm{~mm}$, respectively at 100 $\mu \mathrm{g} /$ disk. Compounds 2 and $\mathbf{5}$ were inactive against $S$. aureus at this level. Compounds 1, 4, and 5 also showed activity against Candida albicans (ATCC 14053) at $100 \mu \mathrm{g} / \mathrm{disk}$, affording inhibition zones of 30,13, and $17 \mathrm{~mm}$, respectively, while compounds $\mathbf{2}$ and $\mathbf{3}$ were inactive in this assay. None of the compounds showed significant activity against Escherichia coli (ATCC 25922) at this level.

Due to sample limitations, only compounds $\mathbf{1}$ and $\mathbf{3}$ were evaluated for activity against Aspergillus flavus (NRRL 6541) and Fusarium verticillioides (NRRL 25457). Assays at 200 $\mu \mathrm{g} /$ disk indicated that both of them have significant activity against $A$. flavus (inhibition zones of 20 and $15 \mathrm{~mm}$, respectively) and $F$. verticillioides (inhibition zones of 20 and $26 \mathrm{~mm}$, respectively). Upon further evaluation, compound 1 displayed MIC values of approximately 10 and $5 \mu \mathrm{g} / \mathrm{mL}$ against $A$. flavus and $F$. verticillioides, respectively. Compound $\mathbf{3}$ was less active than 1 , affording an MIC values of $25 \mu \mathrm{g} / \mathrm{mL}$ against $F$. verticillioides, and $>25 \mu \mathrm{g} / \mathrm{mL}$ against A. flavus (growth of A. flavus was $27 \%$ that of controls at the $25 \mu \mathrm{g} / \mathrm{mL}$ level).

\section{Experimental Section}

\section{General Experimental Procedures}

Optical rotations were determined with a Rudolph automatic polarimeter, model AP III. UV spectra were recorded with a Varian Cary III UV-visible spectrophotometer. ${ }^{1} \mathrm{H}$ and ${ }^{13} \mathrm{C}$ NMR spectra were obtained using Bruker DPX-300 and DRX-400 spectrometers, respectively. HMQC and HMBC data were obtained using a Bruker AMX-600. HPLC was carried out using a Beckman system Gold HPLC instrument with a model 166 detector. Other general procedures and instrumentation have been described previously. ${ }^{17}$

\section{Fungal Material}

Strain A-00267-2A was collected from submerged, decorticated wood in the Lemonweir River, Wisconsin and was identified as Decaisnella thyridioides (Sacc. \& Speg.) M. E. Barr (Pyrenulaceae, Melanommatales, Loculoascomycetes, Ascomycota). A voucher specimen and a subculture of the isolate employed in this work were deposited in the University of Illinois Department of Plant Biology fungal collection with the accession number A-00267-2A.

Ascospores were subcultured onto $250 \mathrm{~g}$ of rice in five two-liter Erlenmeyer flasks (50 $\mathrm{g}$ each) and incubated at $25^{\circ} \mathrm{C}$ under $12 \mathrm{~h} \mathrm{light} / 12 \mathrm{~h}$ dark conditions for five weeks. The fermentation mixture was broken up with a spatula and extracted twice with EtOAc $(2 \times 500 \mathrm{~mL})$. The combined EtOAc was filtered and evaporated to afford $2.3 \mathrm{~g}$ of crude extract.

\section{Extraction and Isolation}

The crude EtOAc extract was partitioned between $\mathrm{CH}_{3} \mathrm{CN}$ and hexanes. The resulting $\mathrm{CH}_{3} \mathrm{CN}$ fraction $(1.7 \mathrm{~g})$ was fractionated by Sephadex LH-20 chromatography using a hexanes/ $\mathrm{CH}_{2} \mathrm{Cl}_{2}$ /acetone solvent system to afford 20 fractions. Fraction $2(398 \mathrm{mg}$ ) was subjected to silica gel column chromatography $\left(\mathrm{CH}_{2} \mathrm{Cl}_{2} / \mathrm{MeOH}\right.$ gradient elution) yielding 10 fractions. Subfraction A $(25 \mathrm{mg})$ contained one major component (palmarumycin $\left.\mathrm{CP}_{1} ; \mathbf{6}\right)$. Subfraction $\mathrm{B}(31 \mathrm{mg})$ was further separated by reversed-phase $\mathrm{HPLC}\left(\mathrm{MeCN} / \mathrm{H}_{2} \mathrm{O}, 50-60 \%\right.$ over $\left.20 \mathrm{~min}\right)$ on a Beckman Ultrasphere $5-\mu \mathrm{m} \mathrm{C}_{8}$ column $(250 \times 10 \mathrm{~mm})$ at a flow rate of $2 \mathrm{~mL} / \mathrm{min}$ with UV detector at $215 \mathrm{~nm}$ to afford compounds $\mathbf{3}(13 \mathrm{mg}), \mathbf{4}(1.1 \mathrm{mg})$, and $\mathbf{5}(1.4 \mathrm{mg})$. Compound 1 precipitated from a $\mathrm{CH}_{3} \mathrm{CN}$ solution of Sephadex $\mathrm{LH}-20$ column fraction 3 (426 mg). After the solid $(116 \mathrm{mg}$ ) was filtered, the filtrate was processed by reversed-phase HPLC under the same conditions as above to obtain compound $2(1.9 \mathrm{mg})$ and an additional sample of compound 1 (40 mg). 
Decaspirone A (1): colorless crystals (from $\left.\mathrm{CH}_{3} \mathrm{CN}\right)$; mp 141-142 ${ }^{\circ} \mathrm{C}$; $[\alpha]^{25} \mathrm{D}+309(c 0.56$, $\mathrm{MeOH}) ; \mathrm{UV}(\mathrm{MeOH}) \lambda_{\max }(\log \varepsilon) 222(5.0) ; 296(3.9) \mathrm{nm} ;{ }^{1} \mathrm{H}$ and ${ }^{13} \mathrm{C}$ NMR data, see Tables 1 and 2; selected HMBC data: $\mathrm{H}-2 \rightarrow \mathrm{C}-1,3,4,4 \mathrm{a}, 8,8 \mathrm{a} ; \mathrm{H}-3 \rightarrow \mathrm{C}-1,4,4 \mathrm{a} ; \mathrm{H}-4 \mathrm{a} \rightarrow \mathrm{C}-1,4$, 5, 6, 8, 8a; H-5 $\rightarrow$ C-4, 4a, 6, 7; H-6 $\rightarrow$ C-4a, 5, 7, 8; H-7 $\rightarrow$ C-5, 6, 8, 8a; H-8 $\rightarrow$ C-4a, 6, 7; $\mathrm{H}-8 \mathrm{a} \rightarrow \mathrm{C}-1,4 \mathrm{a}, 5,8$; EIMS $\mathrm{m} / \mathrm{z} 336\left(\mathrm{M}^{+} \text {; 70), } 318 \text { [(M- } \mathrm{H}_{2} \mathrm{O}\right)^{+} ;$64], 197 (58), 160 (65), 131 (87), 58 (100); ESIMS $m / z 337[\mathrm{M}+\mathrm{H}]^{+}, 354\left[\mathrm{M}+\mathrm{NH}_{4}\right]^{+}, 695[2 \mathrm{M}+\mathrm{Na}]^{+}, \mathrm{HREIMS} \mathrm{m} / \mathrm{z}$ 336.0982 (calcd for $\mathrm{C}_{20} \mathrm{H}_{16} \mathrm{O}_{5}, 336.0998$ ).

Decaspirone B (2): colorless glass; $[\alpha]^{25}{ }_{\mathrm{D}}+171(c 0.085, \mathrm{MeOH})$; UV (MeOH) $\lambda_{\max }(\log$ ع) 218 (4.5); 300 (3.6) nm; ${ }^{1} \mathrm{H}$ and ${ }^{13} \mathrm{C}$ NMR data, see Tables 1 and 2; COSY: H-2 $\leftrightarrow \mathrm{H}-3$; H-3 $\leftrightarrow$ H-4; H-4 ↔ H-4a; H-4a $\leftrightarrow$ H-5; H-5 $\leftrightarrow$ H-6; H-6 $\leftrightarrow$ H-7; H-7 $\leftrightarrow$ H-8; H-8 $\leftrightarrow$ H-8a; $\mathrm{H}-8 \mathrm{a} \leftrightarrow \mathrm{H}-4 \mathrm{a}$; HREIMS $m / z 380.1248$ (calcd for $\mathrm{C}_{22} \mathrm{H}_{20} \mathrm{O}_{6}, 380.1260$ )

Decaspirone C (3): colorless glass; $[\alpha]^{25} \mathrm{D}+89(c 0.58, \mathrm{MeOH})$; $\mathrm{UV}(\mathrm{MeOH}) \lambda_{\max }(\log \varepsilon)$ 225 (4.8); 297 (3.8) nm; ${ }^{1} \mathrm{H}$ and ${ }^{13} \mathrm{C}$ NMR data, see Tables 1 and 2; Selected HMBC data: H-2 $\rightarrow \mathrm{C}-3,4,8,8 \mathrm{a} ; \mathrm{H}-3 \rightarrow \mathrm{C}-1,4 \mathrm{a}, 5 ; \mathrm{H}-4 \mathrm{a} \rightarrow \mathrm{C}-1,4,5,6,8,8 \mathrm{a} ; \mathrm{H}-5 \rightarrow \mathrm{C}-4,6$; H-6 $\rightarrow$ C-4a, 5; $\mathrm{H}-7 \rightarrow \mathrm{C}-8,8 \mathrm{a} ; \mathrm{H}-8 \rightarrow \mathrm{C}-1,4 \mathrm{a}, 5,6$; H-8a $\rightarrow \mathrm{C}-1,4,4 \mathrm{a}, 5,7,8 ;$ HREIMS $m / z: 338.1155$ $[\mathrm{M}]^{+}$(calcd for $\mathrm{C}_{20} \mathrm{H}_{18} \mathrm{O}_{5}, 338.1154$ ).

Decaspirone D (4): colorless glass; $[\alpha]^{25} \mathrm{D}+102\left(c\right.$ 0.055, MeOH); UV (MeOH) $\lambda_{\max }(\log$ ع) 217 (4.6); 276 (3.7) nm; ${ }^{1} \mathrm{H}$ and ${ }^{13} \mathrm{C}$ NMR data, see Tables 1 and 2; COSY: $\mathrm{H}-2 \leftrightarrow \mathrm{H}-3$; H-4a $\leftrightarrow$ H-5; H-5 $\leftrightarrow$ H-6; H-6 $\leftrightarrow$ H-7; H-7 $\leftrightarrow$ H-8; H-8 $\leftrightarrow$ H-8a; H-8a $\leftrightarrow \mathrm{H}-4 a$; EIMS $m / z$ $378\left(\mathrm{M}^{+} ; 5.1\right), 377$ (14), 270 (11), 158 (46), 113 (100).

Decaspirone E (5): colorless glass; $[\alpha]^{25}{ }_{\mathrm{D}}+171(c 0.07, \mathrm{MeOH}) ; \mathrm{UV}(\mathrm{MeOH}) \lambda_{\max }(\log \varepsilon)$ 221 (4.6); 297 (3.7) nm; ${ }^{1} \mathrm{H}$ and ${ }^{13} \mathrm{C}$ NMR data, see Tables 1 and 2; COSY: $\mathrm{H}-2 \leftrightarrow \mathrm{H}-3$; H-4a $\leftrightarrow \mathrm{H}-5 ; \mathrm{H}-5 \leftrightarrow \mathrm{H}-6$; H-6 $\leftrightarrow \mathrm{H}-7$; H-7 $\leftrightarrow \mathrm{H}-8 ; \mathrm{H}-8 \leftrightarrow \mathrm{H}-8 \mathrm{a} ; \mathrm{H}-8 \mathrm{a} \leftrightarrow \mathrm{H}-4 \mathrm{a}$; EIMS $m / 2,378$ $\left(\mathrm{M}^{+}\right.$; 2.1$) 301$ (7.5), 131 (9.1), 115 (100).

\section{X-ray Crystallographic Analysis of Decaspirone A (1)}

18 A needle obtained from $\mathrm{CH}_{3} \mathrm{CN}$ solution $(0.37 \times 0.14 \times 0.12 \mathrm{~mm})$ was found to have crystallized in the orthorhombic class, space group $P 2{ }_{1} 2_{1} 2_{1}$ with cell dimensions $a=7.9766$ (8), $b=10.4205$ (10), $c=38.098$ (4) Å. Crystallographic data were collected on a Nonius Kappa CCD diffractometer (Mo K-alpha radiation, graphite monochromator) at 190(2) K (cold $\mathrm{N}_{2}$ gas steam) using the standard CCD techniques yielding 39938 data. Lorentz and polarization corrections were applied. A correction for absorption using the multi-scan technique also was applied $\left(\mathrm{T}_{\max }=0.9879, \mathrm{~T}_{\min }=0.9633\right)$. Equivalent data were averaged, yielding 4114 unique data $(\mathrm{R}$-int $=0.41,3577 \mathrm{~F}>4 * \operatorname{Sig}(\mathrm{F})$, Friedel pairs averaged). The computer programs from the HKL package were used for data reduction. The preliminary model of the structure was obtained using XS, a direct method program. Least-squares refining of the model vs. the data was performed with the XL computer program. Illustrations were made with the XP program and tables were made with the XCIF program. All are in the SHELXTL V6.1 package. There are two independent molecules in the asymmetric unit that are joined via hydrogen bonds to form a dimer. No further restraints or constraints were imposed on the refinement model. The final refinement gave $R_{1}=0.0391, w R_{2}=0.0940$.

\section{Preparation of $(R)$-MTPA ester $1 \mathrm{a}$ and (S)-MTPA ester $\mathbf{1 b}$}

To a solution of $1(12 \mathrm{mg}, 0.036 \mathrm{mmol})$ in $\mathrm{CH}_{2} \mathrm{Cl}_{2}(2 \mathrm{~mL})$ was added $(S)$-MTPA Cl $(9.0 \mathrm{mg}$, $0.036 \mathrm{mmol}$ ) and DMAP (one crystal). After stirring at ambient temperature for $24 \mathrm{~h}$, saturated aqueous $\mathrm{NaHCO}_{3}$ was added, and the resulting mixture was extracted with $\mathrm{CH}_{2} \mathrm{Cl}_{2}(3 \times 1 \mathrm{~mL})$. The combined organic layers were evaporated to dryness and subjected to reversed-phase HPLC (Alltech Apollo 5- $\mu \mathrm{m} \mathrm{C}_{18}$ column, $250 \times 10 \mathrm{~mm}$; flow rate $2 \mathrm{~mL} / \mathrm{min}$, UV detection at 
$215 \mathrm{~nm}$, eluted with $\mathrm{CH}_{3} \mathrm{CN} / \mathrm{H}_{2} \mathrm{O}, 40-100 \%$ over $\left.30 \mathrm{~min}\right)$ to afford $\mathbf{1 a}(7.2 \mathrm{mg})$ : white solid; ${ }^{1} \mathrm{H}$ NMR (300 MHz, CDCl $) \delta 7.58\left(\mathrm{~d}, J=8.3 \mathrm{~Hz}, \mathrm{H}-4^{\prime}\right.$ or $\left.5^{\prime}\right), 7.49\left(\mathrm{t}, J=7.6 \mathrm{~Hz}, \mathrm{H}-3^{\prime}\right.$ or $\left.6^{\prime}\right), 7.48\left(\mathrm{~d}, J=8.3 \mathrm{~Hz}, \mathrm{H}-5^{\prime}\right.$ or $\left.4^{\prime}\right), 7.28\left(\mathrm{t}, J=7.6 \mathrm{~Hz}, \mathrm{H}-6^{\prime}\right.$ or $\left.3^{\prime}\right), 7.04\left(\mathrm{~d}, J=7.5 \mathrm{~Hz}, \mathrm{H}-2^{\prime}\right.$ or $\left.7^{\prime}\right), 6.99(\mathrm{~d}, J=10 \mathrm{~Hz}, \mathrm{H}-2), 6.60\left(\mathrm{~d}, J=7.5 \mathrm{~Hz}, \mathrm{H}-7^{\prime}\right.$ or $\left.2^{\prime}\right), 6.25(\mathrm{ddd}, J=10,5.4,2.2 \mathrm{~Hz}$, H-7), 6.06 (dd, $J=10,2.5 \mathrm{~Hz}, \mathrm{H}-6$ ), 6.02 (m, H-8), 6.02 (d, $J=10 \mathrm{~Hz}, \mathrm{H}-3), 4.53$ (br d, $J=$ $9.3 \mathrm{~Hz}, \mathrm{H}-5), 4.09$ (br s, 5-OH), 3.31 (dd, $J=13,9.3 \mathrm{~Hz}, \mathrm{H}-4 \mathrm{a}), 2.94$ (dd, $J=13,2.8 \mathrm{~Hz}$, H-8a); EIMS m/z $552\left(\mathrm{M}^{+} ; 23\right), 318$ (4), 189 (100).

In a similar fashion, another sample of compound $1(7.4 \mathrm{mg}, 0.022 \mathrm{mmol}),(R)$ - MTPA Cl (5.6 $\mathrm{mg}, 0.022 \mathrm{mmol}$ ), and DMAP (one crystal) in $\mathrm{CH}_{2} \mathrm{Cl}_{2}(1.5 \mathrm{~mL}$ ) were mixed together, allowed to react at room temperature for $24 \mathrm{~h}$, and processed as described above for $\mathbf{1 a}$ to afford $\mathbf{1 b}$ (2.6 mg): white solid; ${ }^{1} \mathrm{H}$ NMR (300 MHz, $\left.\mathrm{CDCl}_{3}\right) \delta 7.53\left(\mathrm{~d}, J=8.3 \mathrm{~Hz}, \mathrm{H}-4^{\prime}\right.$ or $\left.5^{\prime}\right), 7.48(\mathrm{~d}$, $J=8.3 \mathrm{~Hz}, \mathrm{H}-5^{\prime}$ or $\left.4^{\prime}\right), 7.44\left(\mathrm{t}, J=7.6 \mathrm{~Hz}, \mathrm{H}-3^{\prime}\right.$ or $\left.6^{\prime}\right), 7.19\left(\mathrm{t}, J=7.6 \mathrm{~Hz}, \mathrm{H}-6^{\prime}\right.$ or $\left.3^{\prime}\right), 6.99(\mathrm{~d}$, $J=7.5 \mathrm{~Hz}, \mathrm{H}-2^{\prime}$ or $\left.7^{\prime}\right), 6.91(\mathrm{~d}, J=10 \mathrm{~Hz}, \mathrm{H}-2), 6.37\left(\mathrm{~d}, J=7.5 \mathrm{~Hz}, \mathrm{H}-7^{\prime}\right.$ or $\left.2^{\prime}\right), 6.22$ (ddd, $J$ $=10,5.3,2.1 \mathrm{~Hz}, \mathrm{H}-7), 6.09$ (dd, $J=10,2.5 \mathrm{~Hz}, \mathrm{H}-6), 6.06$ (m, H-8), 5.98 (d, $J=10 \mathrm{~Hz}, \mathrm{H}-3$ ), 4.55 (br d, $J=9.1 \mathrm{~Hz}, \mathrm{H}-5$ ), 4.15 (br s, OH-5), 3.33 (dd, $J=13,9.1 \mathrm{~Hz}, \mathrm{H}-4 \mathrm{a}$ ), 2.92 (dd, $J=$ $13,2.8 \mathrm{~Hz}, \mathrm{H}-8 \mathrm{a})$.

\section{MIC Determinations}

Aspergillus flavus (NRRL 6541) was grown in Roux bottles containing potato dextrose agar (PDA) for $14 \mathrm{~d}\left(25^{\circ} \mathrm{C}\right)$. A conidial spore suspension (propagule density $10^{6} / \mathrm{mL}$ in sterile distilled $\mathrm{H}_{2} \mathrm{O}$ ) prepared from the Roux bottle cultures served as the inoculum. Hyphal fragments and conidium-bearing structures were removed by filtering through a double layer of sterile cheese cloth. Compounds were evaluated in 96-well plates with a growth area of 0.32 $\mathrm{cm}^{2}$ and volume of $370 \mu \mathrm{L}$ (BD Primaria Clear 96-well Microtest Plate No. 353872, BectonDickinson) at concentrations of 1, 3, 5, 10, and $25 \mu \mathrm{g} / \mathrm{mL}$. Appropriate amounts of test compound in $10 \mu \mathrm{L}$ of $\mathrm{MeOH}$ were added to each of eight replicate wells and evaporated to dryness. Eight replicate wells received only $10 \mu \mathrm{L} \mathrm{MeOH}$ and served as controls. Potato dextrose broth (PDB) was seeded with A. flavus conidia, giving a final conidial suspension of approximately $4 \times 10^{4} / \mathrm{mL}$ PDB. A small quantity of $\mathrm{MeOH}(10 \mu \mathrm{L})$ was added to each well to solubilize the test compound, and then $200 \mu \mathrm{L}$ of PDB containing ca. 8,000 A. flavus conidia were added to each test well. The plates were incubated for $48 \mathrm{~h}$ at $25{ }^{\circ} \mathrm{C}$ and examined at 8 $16 \mathrm{~h}$ intervals using a plate reader (Dynatech MR 5000 with BioLinx Version 2.0 Assay Management Software; Dynatech Laboratories, Inc.) for evidence of inhibition of fungal growth in the wells. A minimum inhibitory concentration (MIC) was assigned to the lowest treatment concentration for which no fungal growth was observed. Nystatin was used as a positive control, and gave an MIC value of approximately $10 \mathrm{mg} / \mathrm{mL}$ using this protocol. An analogous process was used for the assay against Fusarium verticillioides NRRL 25457.

\section{Supplementary Material}

Refer to Web version on PubMed Central for supplementary material.

\section{Acknowledgements}

We thank Dr. D. T. Wicklow, USDA National Center for Agricultural Utilization Research, Peoria, IL, for bioassay results against Aspergillus flavus and Fusarium verticillioides. Financial support from the National Institutes of Health (GM 60600) is gratefully acknowledged.

\section{References and Notes}

1. Reategui RF, Gloer JB, Campbell J, Shearer CA. J Nat Prod 2005;68:701-705. [PubMed: 15921413] 
2. Li C, Nitka MV, Gloer JB, Campbell J, Shearer CA. J Nat Prod 2003;66:1302-1306. [PubMed: 14575427]

3. Oh H, Swenson DC, Gloer JB, Shearer CA. Tetrahedron Lett 2001;42:975-977.

4. Jiao P, Gloer JB, Campbell J, Shearer CA. J Nat Prod 2006;69:612-615. [PubMed: 16643037]

5. Krohn K, Michel A, Florke U, Aust H, Draeger S, Schulz B. Liebigs Ann Chem 1994;11:1093-1097.

6. Chu M, Truumees I, Patel MG, Gullo VP, Puar MS, McPhail AT. J Org Chem 1994;59:1222-1223.

7. Krohn K, Beckmann K, Florke U, Aust H, Draeger S, Schulz B, Busemann S, Bringmann G. Tetrahedron 1997;53:3101-3110.

8. Chu M, Truumees I, Patel MG, Gullo VP, Pai J, Das PR, Puar MS. Bioorg Med Chem Lett 1994;4:1539_ 1542.

9. Thiergardt R, Rihs G, Hug P, Peter HH. Tetrahedron 1995;51:733-742.

10. Bringmann G, Busemann S, Krohn K, Beckmann K. Tetrahedron 1997;53:1655-1664.

11. Bode HB, Walker M, Zeeck A. Eur J Org Chem 2000;53:3185-3193.

12. Dale JA, Mosher HS. J Am Chem Soc 1973;95:512-519.

13. Ohtani I, Kusumi T, Kashman Y, Kakisawa H. J Am Chem Soc 1991;113:4092-4096.

14. Upon nearing completion of this manuscript, we became aware that another group had independently isolated and characterized (from a different fungal source) a series of four other compounds that are very close analogues of those described here. Because of the similarities in the structures, a mutual decision was made to name them all as decaspirones, and to submit the corresponding manuscripts simultaneously to the Journal (see Ref. 15).

15. Hu H, Guo H, Li E, Liu X, Zhou Y, Che Y. J Nat Prod. in press

16. Bode HB, Wegner B, Zeeck A. J Antibiot 2000;53:153-157. [PubMed: 10805575]

17. Höller U, Gloer JB, Wicklow DT. J Nat Prod 2002;65:876-882. [PubMed: 12088431]

18. Crystallographic data for compound 1 have been deposited with the Cambridge Crystallographic Data Centre (deposition number CCDC 284776). Copies of the data can be obtained, free of charge, on application to the director, CCDC 12 Union Road, Cambridge CB2 1EZ, UK (fax: +44 1223336033 or e-mail: deposit@ccdc.cam.ac.uk). 


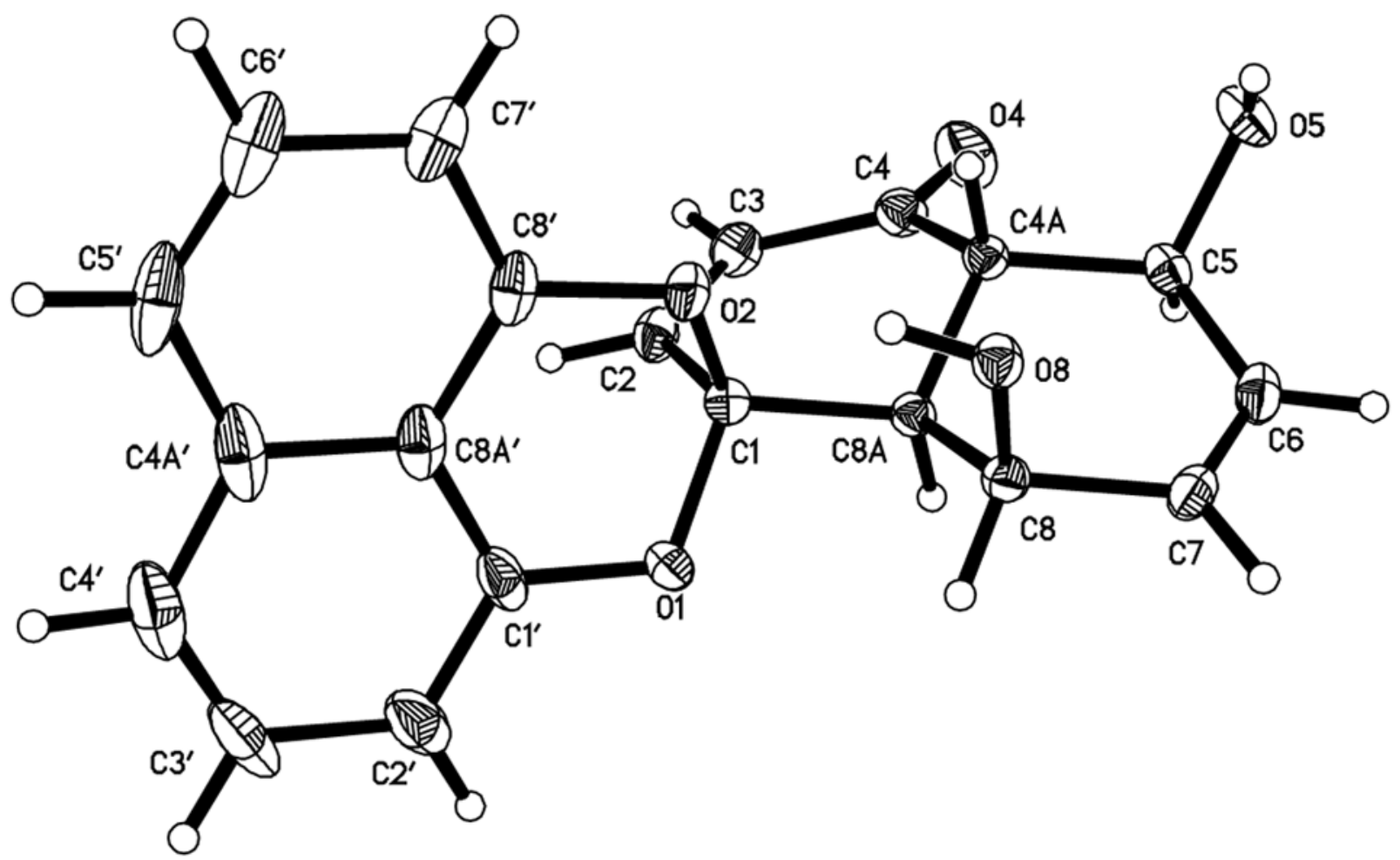

Figure 1.

X-ray crystal structure of decaspirone A (1) 

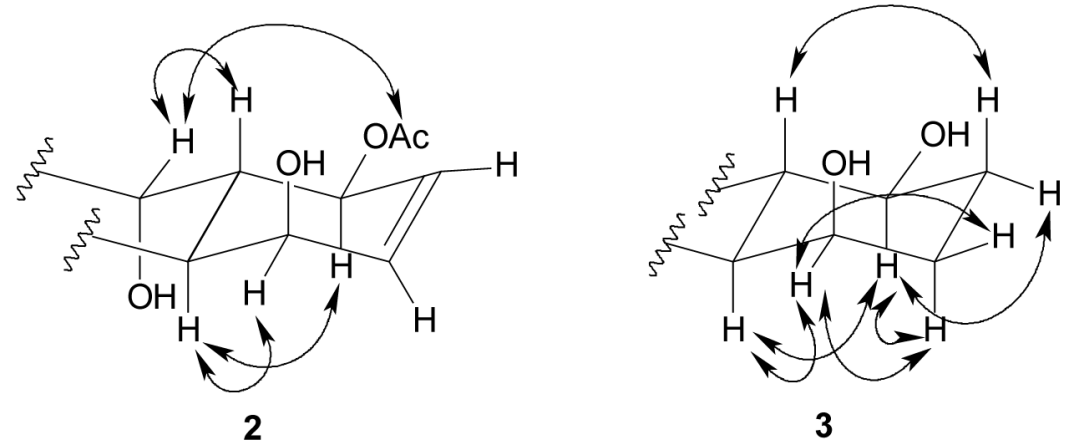

Figure 2.

Key NOESY correlations for decaspirones B (2) and C (3) 

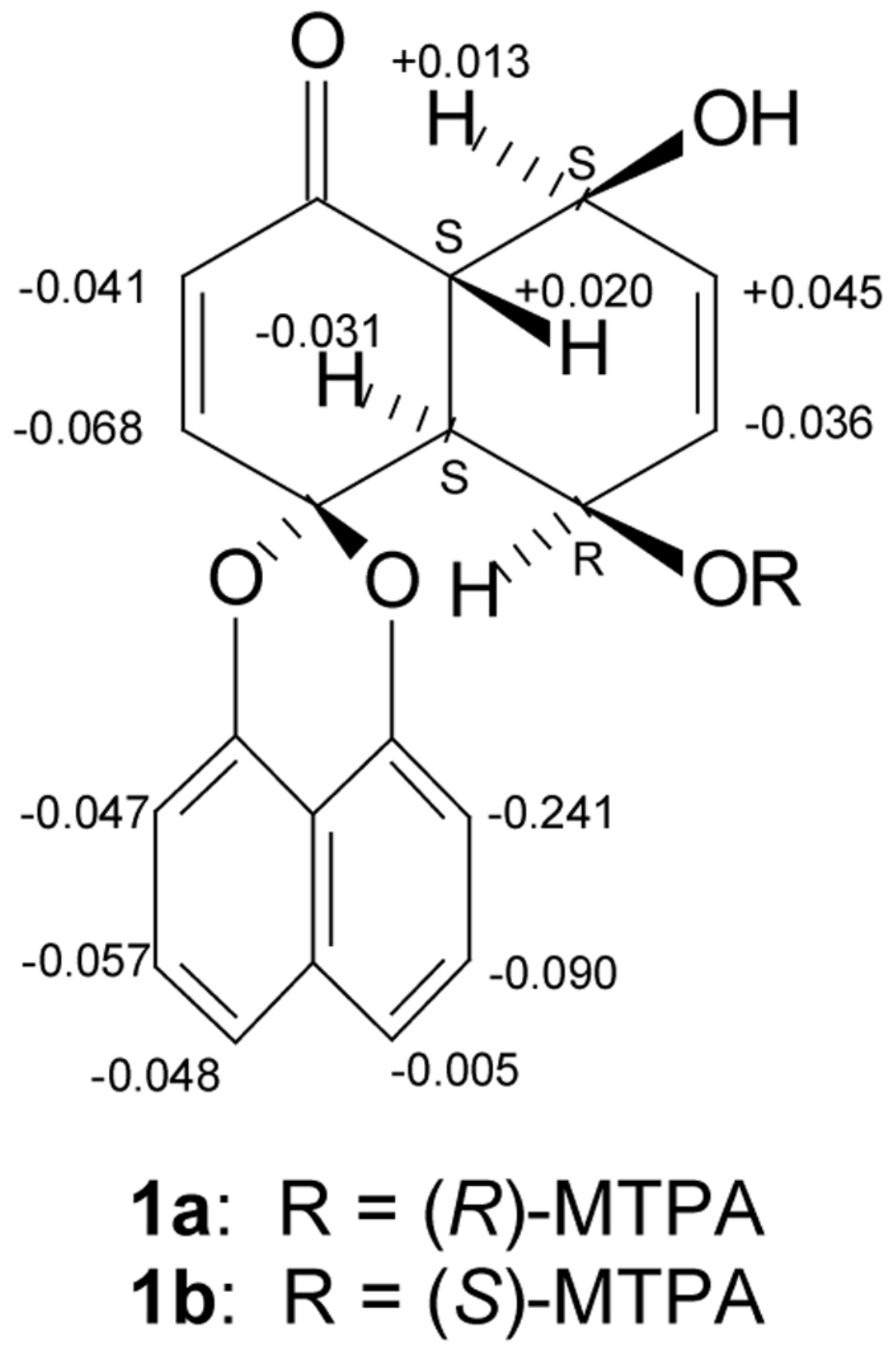

Figure 3.

$\Delta \delta$ values (in ppm) $=\delta_{S}-\delta_{R}$ obtained for $(S)$ - and $(R)$-MTPA esters 1a and $\mathbf{1 b}$ 


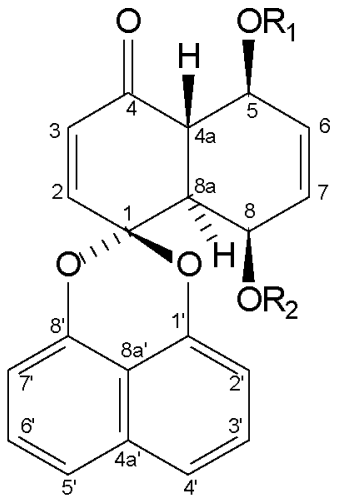

$1 \mathrm{R}_{1}=H \mathrm{R}_{2}=H$
$4 \mathrm{R}_{1}=H \mathrm{R}_{2}=O A C$
$5 \mathrm{R}_{1}=O A C \mathrm{R}_{2}=H$<smiles>O=C1C=CC2(Oc3cccc4cccc(c34)O2)[C@@H]2[C@@H](O)CC[C@H](O)[C@@H]12</smiles>

3<smiles>CC(=O)O[C@H]1C=C[C@@H](O)[C@H]2[C@@]1(O)C=C[C@H](O)[C@]21COc2cccc3cccc1c23</smiles>

2<smiles>O=C1C=CC2(Oc3cccc4cccc(c34)O2)c2cccc(O)c21</smiles>

6 


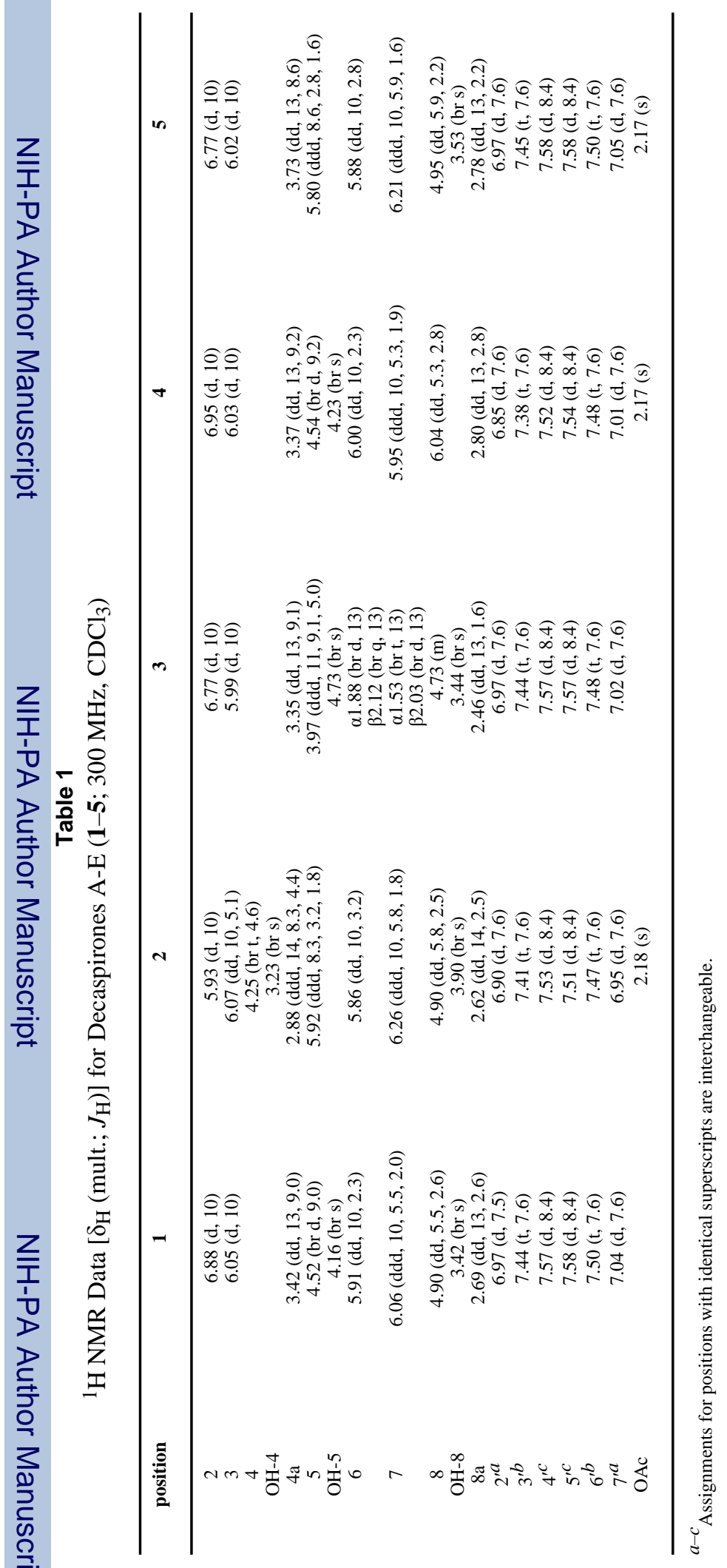




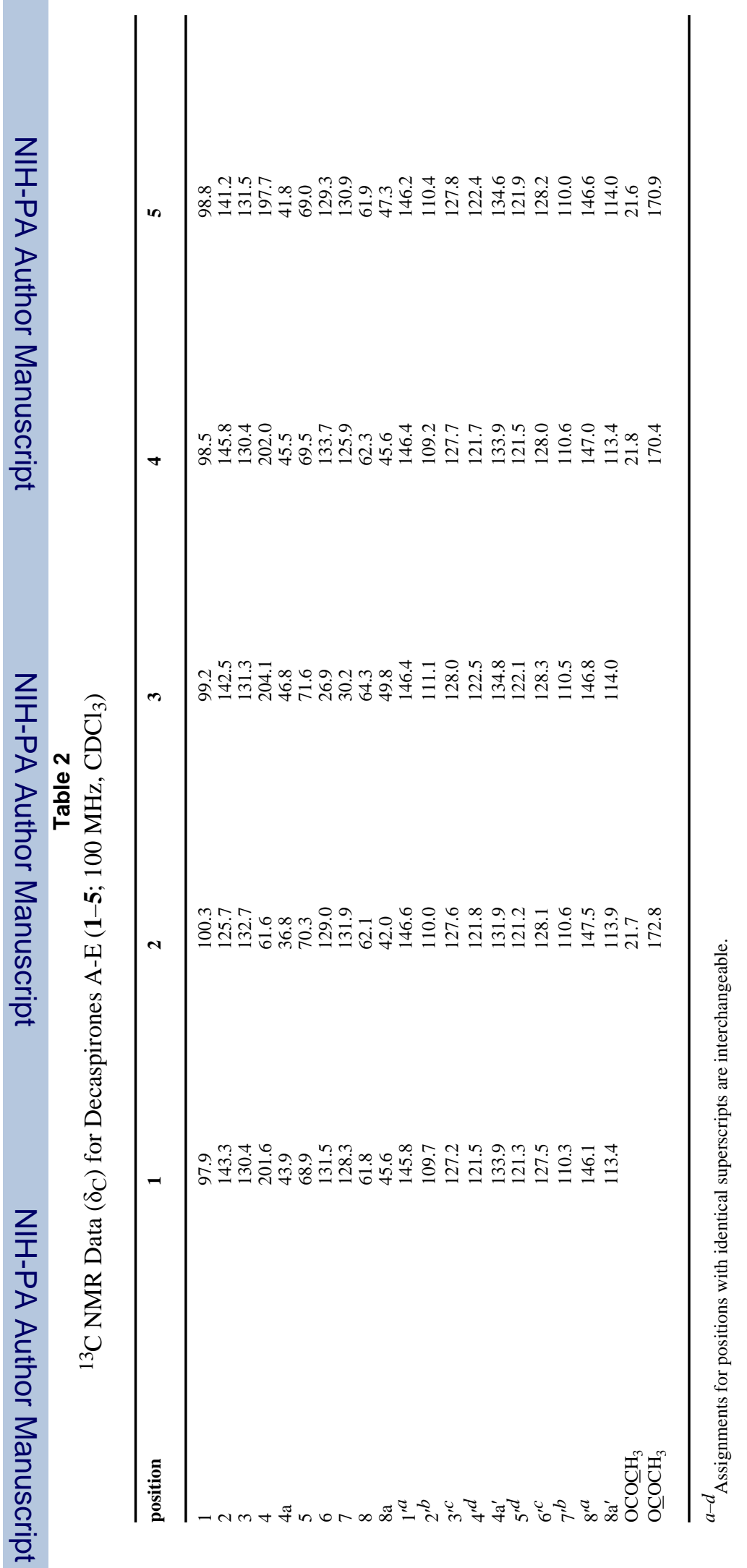

